\title{
HUBUNGAN PAPARAN GADGET DENGAN PERKEMBANGAN EMOSIONAL PADA ANAK USIA REMAJA KELAS VII DAN VIII SMP NEGERI O4 PONTIANAK TIMUR
}

\author{
Lintang Sari ${ }^{1 *}$, Ai Yeni Susanti ${ }^{2}$, Hajimi ${ }^{3}$ \\ ${ }^{1-2}$ STIKes YARSI Pontianak, ${ }^{3}$ Poltekkes Pontianak \\ Lintang Sari: STIKes YARSI Pontianak, Jln. Panglima A'im No. 1, \\ Kota Pontianak, Kalimantan Barat - 78232, E-mail: stikesyarsiptk@yahoo.com
}

\begin{abstract}
Abstrak
Perkembangan mental emosional merupakan proses perkembangan individu dalam usaha menyesuaikan diri dengan lingkungan dan pengalamannya. Masalah mental emosional dapat timbul jika terdapat suatu konflik dalam proses penyesuaian diri dengan lingkungan dan pengalaman pengalamannya. Pertukaran informasi yang begitu cepat dari penjuru dunia ikut membawa budaya luar yang berbeda dengan budaya Indonesia, sehingga dapat menggeser nilai-nilai budaya yang ada. Nilai-nilai budaya asing tersebut dirasakan oleh remaja begitu berbeda dengan nilai spiritual yang telah didapatkan. Situasi ini dapat menimbulkan kebingungan dalam diri remaja sehingga memicu konflik nilai yang berakibat terjadinya penyimpangan perilaku. Tujuan penelitian ini yaitu untuk Menganalisis hubungan paparan gadget dengan perkembangan emosional pada anak kelas VII dan VIII SMP Negeri 04 Pontianak Timur. Rancangan penelitian ini menggunakan uji kolerasi pearson product moment. Disimpulkan bahwa bahwa paparan gadget $>4$ jam dengan interpretasi nilai abnormal yaitu sebanyak $71,1 \%$ yang menunjukkan bahwa ada hubungan yang signifikan antara paparan gadget dengan perkembangan emosional dibuktikan dengan nilai $\mathrm{p}$ value 0,000 kurang dari $\alpha 0,05$.
\end{abstract}

Kata kunci: Gadget, Perkembangan Emosional, Anak, Remaja

\begin{abstract}
Emotional mental development is a process of individual development in an effort to adjust to the environment and experience of experience. Emotional mental problems may arise if there is a conflict in the process of adjusting themselves to the environment and experience of their experience. The rapid exchange of information from all corners of the world brings an outside culture that is different from Indonesian culture, so that it can shift existing cultural values. The values of foreign cultures are felt by adolescents so different from the spiritual values that have been obtained. This situation can lead to confusion in adolescents so that it triggers a conflict of values that results in behavioral irregularities. The purpose of this study is to analyze the relationship between exposure to gadgets and emotional development in children in grades VII and VIII of SMP Negeri 04 East Pontianak. This research design uses pearson product moment correlation test.It was concluded that the exposure of gadgets $>4$ hours with an interpretation of abnormal values is as much as $71.1 \%$ which indicates that there is a significant relationship between exposure to gadgets and emotional development as evidenced by a $p$ value of 0,000 less than $\alpha 0.05$
\end{abstract}

Keywords: Gadgets, Emotional Development, Children, Youth 


\section{PENDAHULUAN}

Kemajuan zaman di bidang ilmu teknologi pada abad ke 21 ini semakin berkembang pesat. Berbagai macam penemuan dengan tujuan mempermudah ruang gerak dan ruang lingkup manusia diciptakan satu persatu setiap tahunnya. Ini membuktikan bahwa daya pikir masyarakat dan juga pola perilaku manusia semakin maju dan berkembang dengan pesat. Sebagai contoh yang berkembang saat ini adalah gadget, yaitu sebuah teknologi yang berkembang pesat dan memiliki fungsi khusus Widiawati dan Sugiman (2014). Gadget merupakan barang canggih yang diciptakan dengan berbagai aplikasi yang dapat menyajikan berbagai media berita, jejaring sosial, hobi, bahkan hiburan. Gadget mejadi media yang dipakai sebagai alat komunikasi modern dan semakin mempermudah kegiatan komunikasi manusia (Jati dan Herawati, 2014).

Beragamnya gadget yang bermunculan dengan keunggulan masing-masing memang sangat berdampak positif jika disikapi dengan baik, namun sebaliknya akan berdampak negatif jika salah dalam mensikapinya. Dampak positif yang dapat timbul adalah menambah pengetahuan tentang perkembangan teknologi, mempermudah komunikasi terutama jarak jauh, sebagai penghibur pada saat jenuh, membantu mencari informasi, dan mempermudah pekerjaan. Selain dampak positif gadget juga menimbulkan efek radiasi yang mampu mempengaruhi kesehatan, rawan tindak kejahatan, mengganggu perkembangan anak, mengakibatkan pemborosan, penyalahgunaan fitur internet yang tidak selayaknya, dan menurunkan mental belajar bagi siswa (Nikmah, 2013).

Survei yang dilakukan oleh Badan Pusat Statistik (BPS) yang bekerja sama dengan Asosiasi Penyelenggara Jasa Internet Indonesia (APJII), mencatat bahwa pengguna internet di Indonesia hingga akhir tahun 2013 mencapai 71,19 juta orang. Jumlah tersebut mengalami kenaikan $13 \%$ dibandingkan dengan hasil survei tahun 2012 yaitu sebanyak
63 juta orang (Manumpil, Ismanto \& Onibala, 2015). Seringnya anak menggunakan gadget ini juga mempengaruhi perkembangan dan pertumbuhan seorang anak, dari sebuah penelitian menemukan bahwa $45 \%$ anak-anak berusia delapan tahun menghabiskan waktu lebih dari dua jam, sementara bagi yang berusia 16 tahun jumlahnya mencapai $80 \%$ (www.republika.co.id).

Setiap tingkatan umur memiliki fase perkembangan yang berbeda baik dari lahir sampai remaja. Anak usia 12-18 tahun dikategorikan sebagai remaja (Wong, 2008). Masa remaja atau masa adolesens merupakan fase transisi masa kanak-kanak ke masa dewasa yang ditandai dengan percepatan tumbuh kembangnya. Setiap orangtua tentunya mengidamkan anak dengan pertumbuhan dan perkembangan yang normal, tetapi tidak jarang terjadi gangguan perkembangan pada anak, tercapainya tumbuh kembang yang optimal bergantung pada hasil interaksi faktor genetik dan lingkungan biofisikopsikososial (Soetjiningsih, 2015).

Remaja saat ini dihadapkan pada kemajuan teknologi yang terus berinovasi. Baik langsung maupun tidak langsung, kemajuan teknologi dapat berpengaruh terhadap perkembangan perilaku dan kepribadian nya dan remaja sangat rentan terhadap risiko-risiko yang ditimbulkan. Jika tak mendapatkan pemahaman secara tepat, maka mereka akan memanfaatkan kecanggihan teknologi pada perilaku yang tidak wajar. Remaja sekarang tak segan untuk memposting foto-foto hingga video yang tak layak mereka lakukan (Riyanti, 2016). Pesatnya perkembangan teknologi dan paparan nya terhadap remaja adalah video game yang dapat mempengaruhi perkembangan mental dan emosional remaja. Video game aksi adalah permainan yang menekankan pada tantangan fisik, kecepatan refleks, dan pertarungan/peperangan tempo cepat sehingga akan terjadi peningkatan emosi sehingga berperilaku lebih agresif (Aderson, 2008). 
Gangguan emosi dan perilaku merupakan ketidakmampuan yang serius dalam perkembangan dan menurunkan produktivitas serta kualitas hidup anak dimana individu mengalami perubahan emosional yang dapat berkembang menjadi patologis. Penelitian WHO tahun 2000 diperoleh data masalah mental sebesar 12\%, tahun 2001 meningkat menjadi $13 \%$ dan diprediksi pada tahun 2020 menjadi $15 \%$.Hasil survei Riset kesehatan dasar (Riskesdas) tahun 2007 menunjukkan bahwa $11.6 \%$ orang Indonesia diatas usia 15 tahun mengalami masalah mental emosional (Sulistiyowati, 2010).

Gadget merupakan salah satu hasil perkembangan teknologi yang diciptakan dalam bentuk perangkat kecil yang penggunaannya semakin meningkat. Jika dipandang dari harga, gadget bukanlah barang yang murah sehingga hanya digunakan oleh orang-orang yang berkepentingan saja, tetapi faktanya anak-anak mulai usia 3 tahun dan remaja pun sudah menggunakannya (Widiawati, 2014).

Berdasarkan hasil penelitian yang dilakukan oleh Trinika, dkk (2015) anak usia prasekolah (3-6 tahun) lebih banyak membuang waktunya untuk terus bermain game saat mereka menggunakan gadget. Hovart (2016) menjelaskan bahwa kecanduan tidak hanya terhadap zat saja, akan tetapi juga pada aktivitas tertentu yang dilakukan berulangulang dan menimbulkan dampak negatif begitupun dengan kecanduan terhadap gadget. Penelitian Mohsin, Mishra \& Sahu (2016) menemukan bahwa remaja perkotaan lebih banyak menggunakan gadget karena keterjangkauan akses dan mereka memiliki pengetahuan lebih mengenai perkembangan teknologi. Remaja perkotaan lebih konsumtif dalam hal penggunaan internet dibandingkan dengan remaja di pedesaan. Penelitian Pawłowska, Zygo, Potembska, Kapkaskrzypczak, \& Dreher, (2015) membandingkan tingkat ketergantungan remaja pada gadget di daerah perkotaan dan pedesaan. Hasil penelitian menemukan ada perbedaan yang signifikan antara penggunaan gadget remaja perkotaan dan pedesaan. Remaja pedesaan pada umumnya hanya menggunakan gadget untuk kepentingan pencarian informasi seperti pencarian tugas sekolah sedangkan interaksi sosial masih sangat bagus dengan teman sebaya di kehidupan nyata sedangkan remaja perkotaan lebih efisien, mereka menggunakan internet untuk segala aspek termasuk menjalin pertemanan.

Hal ini akan menghambat proses sosialisasi anak dan akan menimbulkan ketergantungan pada gadget tersebut. Justru, kadangkala orang tua sengaja memberikan gadget kepada anak mereka agar anak tidak bermain diluar rumah dan bahkan tidak menganggu aktivitas orang tua pada saat dirumah.

Hasil penelitian yang dilakukan oleh Asif dan Rahmadi (2017)menunjukkan bahwa sejak menggunakan gadget, ketika di rumah anak remaja menjadi susah diajak berkomunikasi, tidak peduli dan kurang berespon pada saat orang tua mengajaknya berbicara. Hal tersebut dapat menimbulkan kesenjangan antara anak dengan orang tuanya, lingkungannya, bahkan teman sebayanya.

Hasil studi pendahuluan di SDN 41 Sungai Ambawang, SMPN 04 Pontianak Timur dan SMP Darussalam Pontianak Timur dengan metode wawancara dengan siswa, guru dan orangtua, didapatkan seluruh siswa bermain gadget saat diluar jam sekolah dan memiliki gadgetnya sendiri. Dari hasil wawancara tentang dampak gadget pada 10 orangtua, berpendapat bahwa bermain gadget pada anak ada dampak positifnya dan negatifnya. Sekitar $30 \%$ orangtua mengatakan bahwa dampak positif bermain gadget untuk mengakses ilmu atau mata pelajaran sebagai referensi tambahan dalam belajar.Akan tetapi, $70 \%$ orangtua lainnya mengatakan dampak negatif yang dirasakan lebih banyak seperti malas belajar, ketergantungan terhadap gadget, suka marah jika gadget di ambil/sita, mudah tersinggung, sulit berkonsentrasi ketika belajar, tidak percaya diri, kurang dapat mengekspresikan emosi. Siswa lebih banyak menghabiskan waktunya dengan bermain 
game, bahkan siswa mengatakan dapat lebih mengekspresikan rasa marah dan kesal dengan bermain game, mereka tidak begitu memperhatikan radiasi yang dapat ditimbulkan gadget tersebut.

Berdasarkan paparan diatas yang paling menonjol selain masalah psikososial pada anak, yaitu masalah perilaku, interaksi dengan teman sebaya, dan keluarga, tidak adanya komunikasi dua arah, dan berakibat tidak sempurnanya perkembangan kognitif anak sehingga terbentuk pandangan negatif terhadap lingkungan dan dirinya sendiri. Dari penelitian yang dilakukan sebelumnya dan studi pendahuluan yang telah dilakukan di beberapa SMP,bahwa terdapat guru yang mengatakan sebagian besar siswa/siswi disekolah nya memiliki tingkahlaku yang buruk, seperti suka berkata kotor, mudah tersinggung, tidak mudah menerima nasehat, suka menggerutu dan mengkritik orang lain yang menyebabkan amarah dibandingkan dengan siswa/siswi disekolah lain terutama dalam waktu 4 tahun terakhir. Banyak faktor yang dapat mempengaruhi hal tersebut terutama dalam penggunaan gadget yang mereka miliki.

Sekolah memang jarang dilakukan razia, tetapi dalam sekali melakukan razia guru mendapatkan banyak sekali siswa/siswi membawa gadget kesekolah dan selama proses belajar mengajar banyak sekali kasus yang ditemukan oleh guru bahwa siswa/siswi yang menggunakan gadget tertangkap sedang menonton konten yang tidak seharusnya mereka buka dimedia massa. Selain itu siswa pun pernah melakukan perlawanan pada guru ketika gadget mereka akan disita/ambil. Untuk itu penulis tertarik untuk melakukan penelitian yang berjudul "Hubungan Paparan Gadget dengan Perkembangan Emosional Pada Anak Usia Remaja Kelas VII dan VIII SMP Negeri 04 Pontianak Timur".

\section{METODE PENELITIAN}

Jenis penelitian ini menggunakan metode survey yaitu dengan menggunakan analisis uji korelasi pearson (pearson product moment), uji ini digunakan untuk menguji hubungan antara variabel independen dan variabel dependen yang nilai korelasi (nilai $r$ ) menunjukkan besarnya hubungan dan merupakan data parametrik dengan tingkat kemaknaan 95\%. Penelitian dilakukan pada bulan Mei-Juli yang meliputi penyusunan proposal sampai dengan laporan. Pengambilan data dan penelitian dilakukan pada tanggal 1718 Juni 2018 di SMP Negeri 04 Pontianak Timur. Populasi dalam penelitian ini adalah seluruh siswa/siswi di SMP Negeri 04 PontianakTimur berdasarkan data laporan jumlah siswa/siswi di tahun 2017/2018 dengan jumlah 539 orang.

Pengambilan sampel mengacu pada rumus Slovin metode simple random sampling atau pengambilan sampel secara acak, sehingga terpilih 236 siswa yang memenuhi kriteria penelitian. Instrumen dalam penelitian ini terdiri dari dua kuesioner yaitu kuesioner A (kuesioner paparan gadget) dan kuesioner B (Streght and Difficulties Questionaire/SDQ).

\section{HASIL DAN PEMBAHASAN}

Hasil penelitian menyajikan data tentang demografi responden berdasarkan hasil univariat dan bivariat. Jumlah responden pada penelitian ini sebanyak 236 responden. Pengumpulan data dilakukan 17-18 Juni 2018 dengan tempat penelitian sesuai dengan rencana semula yaitu di SMP Negeri 04 Pontianak Timur. Adapun hasil analisis yang dilakukan adalah sebagai berikut :

\section{a. Durasi paparan Gadget}

Tabel 5.3 Distribusi Responden Berdasarkan Durasi Paparan Gadgetdi SMP Negeri 04 Pontianak Timur Bulan Juli 2018 $\mathrm{n}=236$

\begin{tabular}{ccc}
\hline $\begin{array}{c}\text { Durasi Paparan } \\
\text { Gadget }\end{array}$ & Frekuensi & Persentase (\%) \\
\hline$\leq 4$ jam & 72 & 30,5 \\
$>4$ jam & 164 & 69,5 \\
\hline Total & 236 & 100 \\
\hline
\end{tabular}

Sumber: data primer (diolah 2018) 
Sebagian besar $(69,5 \%)$ durasi paparan gadget responden $>4$ jam. Paparan dengan durasi penggunaan gadget pada anak remaja dan kaitannya dengan tingkat kesejahteraan mental mereka rata-rata durasi ideal untuk melakukan aktivitas online adalah sepanjang 4 jam. Namun ketika remaja menggunakan diatas 4 jam maka barulah gadget dapat mempengaruhi kinerj aotak remaja (Sativa, 2017).

Peneliti berpendapat bahwa anak remaja di SMP Negeri 04 Pontianak Timur dalam penggunaannya rata-rata lebi hdari 4 jam. Hal ini dapat dibuktikan dengan hasi lpernyataan responden tentang berapa jam penggunaan gadget (smartphone) dalamseharipada item kuesioner A (paparangadget). Selain itu menurut hasil wawancara peneliti dengan guru bimbingan konseling (BK), bahwa disekolah juga memang jarang sekali melakukan razia, tapi dalam sekali melakukan razia guru mendapatkan banyak sekali siswa/siswi yang membawa gadget kesekolah. Bahkan dalam beberapa kali saat proses belajar mengajar pun siswa tertangkap menggunakan gadget dan membuka konten-konten yang tidak seharusnya ditonton.Hal ini sesuai dengan pendapat (Sigman, 2013) bahwa efek mendasar dari penggunaan gadget ialah kecanduan/adiksi. Ini terjadi karena saat kita menggunakan dan menatap layar gadget, maka tubuh akan mengeluarkan hormon dopamin yang menimbulkan rasa nyaman dan ketagihan/kecanduan.

\section{b. Perkembangan Emosional Anak Usia Remaja}

Tabel 5.4 Distribusi Responden Berdasarkan Perkembangan Emosional di SMP Negeri 04 Pontianak Timur Bulan Juli 2018 n=236

\begin{tabular}{lll}
$\begin{array}{l}\text { Perkembangan } \\
\text { Emosional }\end{array}$ & Frekuensi & $\begin{array}{l}\text { Persentase } \\
(\%)\end{array}$ \\
\hline Normal & 10 & 4,2 \\
Borderline & 86 & 36,4 \\
Abnormal & 140 & 59,3 \\
\hline Total & 236 & 100 \\
\hline
\end{tabular}

Sumber: data primer (diolah 2018)
Sebagianbesarrespondendalampenelitianini $(59,3 \%)$ memiliki interpretasiskor abnormal. Masalah mental emosional merupakan proses perkembangan individu dalam usaha menyesuaikan diri dengan lingkungan dan pengalamannya. Masalah tersebut akan timbul jika terdapat suatu konflik dalam proses penyesuaian diri dengan lingkungan dan pengalaman-pengalamannya (Alves, 2011).

Melihat dari pedapat diatas maka masalah perkembangan mental emosional tentunya tidak hanya dapat dilihat dari satu sisi. Namun dari faktor pencetus yang diidentifikasi dapat meningkatkan resiko terjadinya masalah mental emosional remaja, seperti individu, keluarga, sekolah, peristiwa hidup, dan sosial. Secara biologis individu berpengaruh terhadap perkembangan mental emosional karena dapat dilihat dari genetik, usia dan jenis kelamin. Seperti yang telah peneliti paparkan sebelumnya dengan kondisi perkembangan remaja yang masih berubah-ubah dan belum dapat menentukan pilihan.

Masalah mental emosional remaja dipengaruhi oleh interaksi antara faktor resiko dan faktor protektif, dengan memperkuat faktor protektif dan menurunkan faktor resiko maka akan tercapailah kematangan kepribadian dan kemandirian sosial remaja (IDAI, 2014). Namun seiring dengan berjalannya waktu dan berkembangnya zaman serta tekhnologi, faktor-faktor resiko yang menyebabkan masalah mental emosional remaja kemungkinan juga ikut berkembang.Sehingga dapat muncul faktor lain yang berpengaruh terhadap perkembangan mental emosional individu.

Analisis hubungan antara paparan gadget dengan perkembangan emosional anak usia remaja SMP Negeri 04 Pontianak Timur disajikan sebagai berikut:

Tabel 5.5 Hubungan Antara Paparan Gadget dengan Perkembangan Emosional Anak Usia Remaja Kelas VII dan VIII SMP Negeri 04 Pontianak Timur Bulan Juli 2018 $\mathrm{n}=236$ 


\begin{tabular}{|c|c|c|c|c|c|c|c|c|c|c|}
\hline \multirow{3}{*}{$\begin{array}{l}\text { Paparan } \\
\text { Gadget }\end{array}$} & \multicolumn{10}{|c|}{ Perkembangan Emosional } \\
\hline & \multicolumn{2}{|c|}{ Normal } & \multicolumn{2}{|c|}{ Borderline } & \multicolumn{2}{|c|}{ Abnormal } & \multicolumn{2}{|c|}{ Total } & \multirow[t]{2}{*}{$p$ value } & \multirow{2}{*}{$\begin{array}{l}\text { Koefisien } \\
\text { korelasi }\end{array}$} \\
\hline & $\mathrm{n}$ & $\%$ & $\mathrm{~N}$ & $\%$ & $\mathrm{n}$ & $\%$ & $\mathrm{n}$ & $\%$ & & \\
\hline$\leq 4 \mathrm{Jam}$ & 5 & 10,2 & 37 & 75,5 & 7 & 14,5 & 49 & 100 & \multirow{3}{*}{0,000} & \multirow{3}{*}{0,453} \\
\hline >4 Jam & 5 & 2,7 & 49 & 26,2 & 133 & 71,1 & 187 & 100 & & \\
\hline Total & 10 & 4,2 & 86 & 36,4 & 140 & 59,3 & 236 & 100 & & \\
\hline
\end{tabular}

Tabel 5.5 Menunjukkaan persentase anak dengan status perkembangan emosional border line lebih tinggi pada kelompokanak dengan paparan gadget $\leq 4$ jam. Dan menunjukkan persentase anak dengan status perkembangan emosional abnormal lebih tinggi pada kelompok anak dengan paparan gadget yang lebih sering atau (>4 jam). Nilai untuk hubungan antara paparan gadget dan perkembangan emosional $p 0,000$. Hal iniberarti $\mathrm{H}_{0}$ ditolakdan $\mathrm{H}_{\mathrm{a}}$ diterima yang menunjukkan ada hubungan bermakna antara paparan gadget dengan perkembangan emosional anak usia remaja di SMP Negeri 04 Pontianak Timur. Kekuatan hubungan cukup yaitu kisaran $(0,41-0,60)$ dengan korelasi positif yang berarti adanya korelasi, semakin lama durasi paparannya maka semakin terganggu perkembangan emosionalnya.

Durasi adalah lamanya sesuatu berlangsung (Sunendar, 2016). Durasi dalam penelitian ini dibagi dalam dua kategori yaitu $\leq 4$ jam dan $>4$ jam. Berdasarkan penelitian Andrew (2017) yang dimodifikasi oleh peneliti karena tidak ditemukan sumber asli pembagian durasi papran gadget.

Berdasarkan hasil penelitian didapatkan hasil bahwa $75,5 \%$ perkembangan emosional anak berada pada interpretasi skor borderline. Hal tersebut menunjukkan bahwa perkembangan remaja dalam masa pertengahan mengalami perubahan emosional yang perlu diaspadai.Karena masa remaja ini memang penuh dengan gejolak emosi yang naik turun dan remaja belum dapat mengendalikannya dengan baik. Selain itu terdapat sebagian besar responden $(71 \%)$ terpapar gadget dengan durasi $>4$ jam dan memiliki perkembangan emosional abnormal.

Gejala emosional mempunyai dampak yang serius, gambaran masalah mental emosional seperti ketidak mampuan memecahkan masalah, gangguan perhatian, hiperaktivitas, perilaku bertentangan (tidak suka ditegur/masukan positif, tidak mau iku taturan) dan perilaku agresif dapat saja terjadi apabila tidak segera ditangani dengan baik karna masa remaja ini mentukan bagaimana dari hasil pengalaman-pengalaman dan lingkungan menentukan ketikaia dewasa dan memiliki peran dalam masyarakat. Untuk itu deteksi dini harus segera dilakuaka nagar dapat segera ditindak lanjuti lebih awal (Alves, 2014).

Berdasarkan penelitian lain yang dilakukan oleh Anggraini (2013) dalam penelitian Asif dan Rahmadi (2017) diperoleh (52,0\%) anak mengalami kecanduan gadget dengan menunjukkan bahwa sejak menggunakan gadget, ketika dirumah anak akan menjadi susah diajak berkomunikasi, tidak peduli dan kurang berespon pada saat orang tua mengajaknya berbicara. Hal tersebut dapat menimbulkan kesenjangan antara anak dan orangtuanya, lingkungannya, bahkan teman sebayanya. Sebagian besar $(42,7 \%)$ perkembangan emosional berada pada interpretasi skor abnormal. Sementara 20\% anak berada pada interpretasi skor borderline. Penelitian tersebut sejalan dengan penelitian ini rata-rata anak berada pada interpretasi skor abnormal dengan bermain $>4$ jam dalam sehari. 
Semakin sering durasi paparan gadget anak memainkan dalam masa formatif (sampai 3 tahun) semakin besar kemungkinan mereka menderita gangguan dalam memusatkan perhatian (attention disorder). Kemampuan interaktif anak saat bermain gadget justru menjadi titik lemahnya. Hal ini terjadi karena saat kita menggunakan dan menatap layar gadget maka tubuh akan mengeluarkan hormom dopamin yang menimbulkan rasa nyaman dan ketagihan/kecanduan (Kaha, 2012 dalam Santoso dkk, 2013).

Saat sedang bermain gadget anak sering tidak merespon saat dipanggil seperti saat orang sedang dalam konsentrasi penuh dengan layar gadget. Namun secara psikologis perilaku tersebut sama seperti anak-anak yang asyik bermain lego, perbedaan nya ketika bermain lego, si anak sendiri yang memutuskan kapan ia selesai bermain. Jika dibandingkan dengan permainan gadget, lego memiliki beberapa nilai kelebihan yang bisa bermanfaat untuk mengasah imajinasi, kreatifitas, dan memicu penggemarnya untuk memiliki rasa gembira, belajar dan mau peduli dengan sesama, dan sampai saat ini belum ditemukan fakta terkait dampak negtaif permainan lego untuk anak (Aanfien,2012). Dikomputer tablet, aplikasinyalah yang menentukan apakah game itu dimainkan dengan benar. Dan akibatnya anak tidak dapat lancar bersosialisasi atau berkomunikasi dengan sekitarnya (Santoso, dkk. 2013).

Berbagai stresor psikososial dapat mempengaruhi perkembangan anak hingga ia tumbuh dewasa, salahsatunya kemajuan danpenggunaanilmupengetahuan dan tekhnologi. Hal tersebutyang semakin meningkat setiap tahunnya dan memberi dampak pada perkembangan remaja seperti peningkatan hiperaktivitas, kesulitan dalam berkonsentrasi, serta lebih banyak merasa sedih atau bosan dengan teman sebaya dan terutama masalah mental dan emosional.Hal ini sejalan dengan penelitian yang dilakukan oleh Wiguna dkk (2010), sekitat 161 anak usia remaja menunjukkan bahwa $54,18 \%$ mengalami masalah dengan teman sebaya dan 42,2\% mengalami masalah emosional.

Menurut Hurlock (2012) pada usia 12-16 tahun merupakan tahun kehidupan yang penuh kejadian sepanjang menyangkut pertumbuhan dan perkembangan. Perkembangan fisik yang cepat dan penting disertai dengan cepatnya perkembangan mental, terutama pada awal masa remaja semua perkembangan itu memerlukan penyesuaian untuk membentuk sikap, nilai dan minat baru. Masa peralihan dari satu tahap perkembangan ke tahap berikutnya yang telah terjadi sebelumnya akan meninggalkan bekas pada apa yang terjadi sekarang dan yang akan datang. Tingkat perubahan dalam sikap dan perilaku selama masa remaja sejajar dengan tingkat perubahan fisik yang bersifat universal. Seperti meningginya emosi yang intensitasnya bergantung pada tingkat perubahan fisik dan psikologis yang terjadi. Karena perubahan emosi biasanya terjadi lebih cepat selama masa awal dan pertengahan remaja, maka meningginya emosi lebih menonjol pada masa awal periode akhir masa remaja.

Pada penelitian ini didapatkan bahwa perkembangan emosional anak usia remaja dengan durasi paparan gadget dalam penelitian ini berada pada tahap remaja tengah sebanyak 222 anak $(94,1 \%)$. Hal ini menunjukkan bahwa periode peralihan remaja dalam menetukan sikap dan perilaku juga perubahan emosional remaja akan berlangsung hingga tahap awal remaja akhir dengan emosional yang menonjol dan stabil.

Bedasarkan hasil wawancara dengan guru dan orangtua saat studi pendahuluan di SMP Negeri 04 Pontianak Timur bahwa bermain gadgetitu ibarat dua sisi mata pisau. Bisa membawa kebaikan dan disisi lain bisa membawa keburukan bagi penggunanya karena tidak sedikit kejadian negatif akibat penyalahgunaan tekhnologi. Seperti postingan kekerasan fisik, menyebar konten video porno, sampai perkenalan pelajar sehingga suka sama suka lalu berujung penculikan (Rohani, 2017). Sedangkan menurut orangtua penggunaan 
gadget dapat memberi dampak positif dan negatif. Namun, sebagian besar orangtua mengatakan dampak negatif yang lebih banyak dirasakan seperti malas belajar, ketergantungan, sulit berkonsentrasi, mudah tersinggung dan emosional. Untuk itu perlu menjadi perhatian khusus untuk tenaga pendidik dan orangtua agar lebih selektif dalam melakukan pengawasan terhadap anak disekolah maupun dirumah agar dapat menggunakan gadget sesuai kebutuhan saja.

Salah satu faktor yang dapat mempengaruhi perkembangan remaja adalah gadgetyang mana gadget merupakan salah satu faktor eksternal dari lingkungan remaja. Gadget adalah sebuah alat perangkat yang memiliki fungsi khusus dimana penggunanya akan merasa nyaman dan praktis dalam menggunakan. Gadget dapat menimbulkan efek yang sangat besar seperti radiasi, yang apabila gadget tersebut digunakan oleh anak remaja yang dalam masa pertumbuhan dan dalam jangka waktu lama dapat memicu timbulnya sel kanker dan kerusakan mata. Selain radiasi internet juga mempengaruhi pembelajaran dan perkembangan anak yang seharusnya lebih selektif dalam memberikan pengawasan oleh orangtua (Soetjiningsih, 2015).

Pada dasarnya penggunaan gadget pada remaja dapat diminimalisir dengan cara membuat kegiatan atau rutinitas anak yang tidak hanya terpaku pada gadget.Pengetahuan dan juga peran orang tua sangat penting dalam mendukung juga memfasilitasi anak sesuai perkembangannya misalnya pada remaja lebih diarahkan perannya dalam menulis, bermain alat musik, sanggar tari dan lain sebagainya yang dapat mengembangkan kreatifitas yang anak miliki.

Dengan demikian seperti yang telah penulis paparkan diatas mengenai peran guru, orangtua, masyarakat serta tenaga kesehatan dalam menghadapi era teknologi dan perkembangan remaja perlu dilakukan Pendidikan kesehatan sedini mungkin untuk memperluas pengetahuan serta mencegah sejak dini penggunaan gadget sesuai dengan kebutuhan dan batas normal pada anak.

Segala sesuatu yang berlebihan memang tidak baik, Allah dan rasul-Nya telah jauh mengingatkan larangan berlebih-lebihan, termasuk berlebih-lebihan dalam bermain gadget apalagi tanpa pengawasan dan batasan dari orangtua. Allah berfirman: "Hai ahli kitab, janganlah kamu berlebih-lebihan (melampaui batas) dengan cara tidak benar dalamagamamu. Dan janganlah kamu mengikuti hawa nafsu orang-orang yangtelah sesat dahulu (sebelum kedatangan muhammad)dan mereka telah menyesatkan kebanyakan (manusia), dan mereka tersesat dari jalan yang lurus”. (Q.S. Al-Maidah: 77).

Dari Ibnu Mas'ud ra, bahwa Nabi Saw bersabda, "binasalah orang-orang yang berlebih-lebihan”. (H.R. Muslim: 2670) dalam riwayat ini tiga kali rasulullah menyebutkannya, baik dengan berita kehancuran mereka ataupun sebagai do'a untuk kehancuran mereka.

Penelitian yang dilakukan saat ini masih memiliki banyak kekurangan dan keterbatasan, di antaranya adalah Masih terdapat jawaban kuesioner yang tidak konsisten menurut pengamatan peneliti. Karena responden yang cenderung kurang teliti terhadap pernyataan yang ada sehingga terjadi tidak konsisten terhadap jawaban kuesioner. Hal ini bisa diantisipasi peneliti dengan cara mendampingi dan mengawasi responden dalam memilih jawaban agar responden fokus dalam menjawab pernyataan yang ada.

\section{KESIMPULAN}

Berdasarkan hasil dan analisis hasil penelitian, secara umum dapat disimpulkan bahwa hampir seluruhnya usia responden paling banyak berusia 13-15 tahun yaitu sebesar 94\% dan yang paling sedikit ditemui berusia 10-12 tahun sebesar 2.1\%.Mayoritas responden berjenis kelamin perempuan sebanyak $58,5 \%$ dan responden berjenis kelamin laki-laki 
sebanyak 41,5\%. Sebagian besar durasi paparan pada responden yaitu $>4$ jam sebanyak $69,5 \%$ dan selebihnya persentase terpapar gadget $\leq 4$ jam. Tingkat perkembangan emosional responden terbanyak berada pada interpretasi nilai abnormal sebanyak $64,8 \%$. Melalui perhitungan dan uji statistik korelasi person produk moment didapatkan hasil bahwa paparan gadget $>4$ jam dengan interpretasi nilai abnormal yaitu sebanyak $71,1 \%$ yang menunjukkan bahwa ada hubungan yang signifikan antara paparan gadget dengan perkembangan emosional dibuktikan dengan nilai $p$ value 0,000 kurang dari $\alpha 0,05$.

Dari hasil penelitian diharapkan orangtua memegang peranan penting dalam perkembangan anak dan tumbuh kembangnya dan orangtua yang baik sangat penting untuk memperhatikan permainan anak dan mampu menyeleksi dan membatasi lebih ketat permainan terutama gadget, memberikan batasan waktu bermain sesuai usia, memberikan fasilitas yang dapat mengembangkan kreatifitas anak sesuai tumbuh kembangnya, dan melakukan skrining dini gangguan perkembangan pada anak.

Selain itu diharapkan bagi institusi dapat bekerjasama dengan tenaga kesehatan dalam memberi arahan kepada siswa dalam memilih permainan dan memanfaatkan gadget sebagai suatu sarana belajar yang baik dengan batasan waktu tertentu serta penggunaannya sesuai kebutuhan agar dapat meminimalisir dampak yang akan ditimbulkan pada perkembangan anak. Bagi institusi kesehatan sebaiknya dapat melatih pusat pelayanan masyarakat tentang batasan waktu bermain gadget yang tepat untuk perkembangan anak yang baik dengan cara melakukan edukasi, menjadi konselor, dan promosi kesehatan pada masyarakat teutama orangtua dan guru. Serta Meningkatkan kerjasama pelayanan kesehatan dengan orangtua untuk memantau perkembangan emosional anak agar dapat diketahui perkembangan remaja yang mengalami masalah perkembangan emosional dengan cara melatih cara skrining dini gangguan perkembangan pada anak. Peneilti selanjutnya bisa mencari faktor-faktor lain dari gadget yang dapat mempengaruhi perkembangan emosional anak usia remaja seperti lama penggunaan gadget dalam tahun, jenis aplikasi yang digunakan, dan jenis gadget yang digunakan yang dapat mempengaruhi perkembangan emosional.

\section{UCAPAN TTERIMA KASIH}

Tim peneliti dengan judul Hubungan Paparan Gadget Dengan Perkembangan Emosional Pada Anak Usia Remaja Kelas VII Dan VIII SMP Negeri 04 Pontianak Timur mengucapkan terimakasih kepada SMP Negri 04 Pontianak Timur dan STIKes Yarsi Pontianak atas dukungannya sehingga penelitian ini dapat terlaksana dengan baik.

\section{REFERENSI}

Ali M \& Asrori M. 2004. Psikologi Remaja. Jakarta: Bumi Aksara

Al-Mighwar, Muhammad.2011. Psikologi Remaja. Volume 2. Bandung: Pustaka Setia.

Alves D, Roysamb E, Oppedal B, Zachrisson H. 2011. Emotional problems in preadolescents in norway: the role of gender, ethnic minority status, and home- and school-related hassles. Available from: Child and Adolescent Psychiatry and Mental Health

Anderson, John R. 2008. Problem Solving and Learning. American Psychologist. Vol. 48. No. I. 35-4-1

Anggraini, R. 2014.Hubungan Pola Asuh Orang Tua dengan Motivasi Belajar Siswa. Jurnal Ilmiah Pendidikan Bimbingan dan Konseling

Arikunto, Suharsini. 2010. Prosedur Penelitian. Jakarta: Rinika Cipta

Asif, A.R \&Rahmadi, F.A. 2017. Hubungan Tingkat Kecanduan Gadget Dengan Gangguan Emosi Dan Perilaku Remaja 
Usia 11-12 Tahun. Jurnal Kedokteran Diponegoro, Vol. 6, Nomor 2. 149-150

Balitbang Kemenkes RI. (2013). Riset Kesehatan Dasar (RISKESDAS) 2013. Jakarta: Balitbang Kemenkes RI.

Budiman\& Riyanto A. 2013. Kapita Selekta Kuisioner Pengetahuan Dan Sikap. Dalam Penelitian Kesehatan. Jakarta : Salemba Medika

Bungin, B. 2005. Metodologi Penelitian Kuantitatif. Jakarta: Kencana Prenada Media Group

Dahlan, Sopiyudin. 2014. Statistika untuk Kedokteran dan Kesehatan Edisi 6. Jakarta: Salemba Medika

Dharma K. Kelana. (2011). Metedologi Penelitian Keperawatan : Panduan Melaksanakan dan Menerapkan Hasil Penelitian. Edisi Revisi. Jakarta: Trans Info Medika

Donna L. Wong, et all. 2008. Buku Ajar Keperawatan Pedriatik. Cetakan pertama. Jakarta : EGC.

Harfiyanto. D. 2015. Pola Interaksi Sosial Siswa Pengguna Gadget Di SMA Negeri 1 Semarang. Journal Of Educational Social Studies, 2,1-5

Hartanto F, \&Selina H. Prevalensi masalah mental emosional pada remaja di kota semarang dengan menggunakan kuesioner kekuatan dan kesulitan (SDQ). Paediatrica Indonesiana. 2011; 51(4)30.

Herawati. A. 2015. Segmentasi Mahasiswa Program Studi Ilmu Komunikasi Universitas Atma Jaya Yogyakarta (UAJY) Dalam Menggunakan Gadget. E-journal UAJY, 2, 1-16

Hurlock, E, B. 2011. Psikologi Perkembangan : Suatu Pendekatan Sepanjang Rentang Kehidupan. Jakarta: Erlangga

IDAI. Masalah kesehatan mental dan emosional remaja. Available from: http://idai.or.id/public-articles/seputarkesehatan-anak/masalah-kesehatan- mentalemosional-remaja.html. (Accesed 15 Maret 2018).

Kementerian Pendidikan Nasional Pusat Data dan Statistik Pendidikan. 2011. Ikhtisar Data Pendidikan Nasional Tahun 2009/2010. Diakses dari http://www.pdsp.kemdiknas.go.id (3 April 2018).

Manimpul. B. 2015. Hubungan Penggunaan Gadget Dengan Tingkat Prestasi Siswa Di SMA Negeri 9 Manado. E-journal Keperawatan, 2, 1-6

Maulida dalam Beauty Manumpil, Yudi Ismanto, Franly Onibala. "Hubungan Penggunaan Gadget dengan Tingkat Prestasi Siswa di Sma Negeri 9 Manado". E-Journal Keperawatan (eKep) Vol.3, Nomor 2. April 2015.

Muttaqin, E. (2012). The Effect of Emotion Regulation Training to Reduce Stress Among Unemployed Individual at Salafusolikhin Pekalongan Central Java. Skripsi. Yogyakarta: Fakultas Psikologi UAD

Nikmah, A. (2013) Dampak Penggunaan Hand Phone Terhadap Prestasi Siswa. Ejurnal Dinas Pendidikan Kota Surabaya, 5: 1-8

Notoatmodjo Soekidjo. (2012). Metedologi Penelitian Kesehatan. Jakarta : Rineka Cipta

Oktaviana \& Mimbarwati, 2014. Validasi Klinik Strenghts and Difficulties Questionnaire $(S D Q)$ sebagai Instrumen Skrining Gangguan Tingkah Laku. Jurnal Psikologi. Volume 41 No. 1, 101114

Rae G N, Thomas H, Offord D R, Boyle M H. Risk, Protective Factors, and the Prevalence of Behavioral and Emotional Disorders in Children and Adolescents. J. Am. Acad. Child Adolesc. Psychiatry. 1989. 28(2):262268.

Sarwono. 2007. Psikologi Remaja. Jakarta: Raja Grafindo Persada. 
Simamora, Antonius,. SM. 2016. Persepsi orangtua terhadap dampak penggunaan gadget pada anak usia pendidikan dasar di perumahan bukit kemiling permai kecamatan kemiling Bandar lampung. Lampung: Universitas Lampung

Soedjatmiko, 2008. Peranan TPA (Tempat Penitipan Anak) Dalam Upaya Pembinaan Tumbuh-Kembang Anak dalam Buku Ajar 2 Tumbuh Kembang Anak dan Remaja Edisi 1. Jakarta: Sagung Seto.

Soedjatmiko. 2008. Tumbuh Kembang Anak. Jakarta: EGC.

Soetjiningsih, 2012. Tumbuh Kembang Anak. Jakarta: EGC

Sugiyono. 2011. Metode Penelitian Kuantitatif, Kualitatif dan $R \& D$. Bandung: ALFABETA

Sulistyowati, Indah dkk. 2010. Pengaruh Return on Asset (ROA), Return on Equity (ROE) dan Growth terhadap Kebijakan Dividen dengan Good Corporate Governance (GCG) sebagai Variabel Intervening. Simposium Nasional Akuntansi XIII Purwokerto. Jakarta: Universitas Negeri Jakarta.

Sunendar, D. 2016. Kamus Besar Bahasa Indonesia Edisi IV. Jakarta: KBBI Daring

Swarjana, I Ketut. 2012. Metodologi Penelitian Kesehatan. Jakarta: Penerbit ANDI.

Trinika Yuli. (2015). Pengaruh Penggunaan Gadget Terhadap Perkembangan Psikososial Anak Usia Prasekolah (3-6 tahun) Di Tk Swasta Kristen Immanuel. Pontianak: Naskah Publikasi Universitas Tanjung Pura

Utami, D. P. (2012). Masalah mental dan emosional pada siswa SMP kelas akselerasi dan regular. Di unduh dari http://eprints.undip.ac.id/37470/.

Widiawati I, Sugiman H, Edy. 2014. Pengaruh Penggunaan Gadget Terhadap Daya
Kembang Anak. Seminar Nasional Multidisiplin Ilmu.106-12.

Widiawati, I, Sugiman, H \& Edy. 2014. Pengaruh Penggunaan Gadget Terhadap Daya Kembang Anak. Jakarta: Universitas Budi Luhur. E-journal Keperawatan, 6, 1-6

World Health Organization. The World Health Report 2001: Mental health new understanding, new hope. Geneva (Switzerland): World Health Organization; 2001.

www.republika.co.id diakses pada tanggal 02 Februari 2018 